\title{
A NEW SPECIES IN THE COHNIELLA ASCENDENS COMPLEX FROM AMAZONIAN VENEZUELA (ORCHIDACEAE, ONCIDIINAE)
}

\author{
William CetZal-Ix ${ }^{1,2,5}$, Germán Carnevali ${ }^{2,3}$ \& Eliana Noguera-Savelli ${ }^{4}$
}

${ }^{1}$ El Colegio de la Frontera Sur (ECOSUR), Unidad Chetumal, Av. del Centenario km 5.5, Chetumal 77014, Quintana Roo, México

${ }^{2}$ Current address: Herbarium CICY, Centro de Investigación Científica de Yucatán, A.C. (CICY), Calle 43. No. 130. Col. Chuburná de Hidalgo, Mérida 97200, Yucatán, México

${ }^{3}$ Orchid Herbarium of Oakes Ames, Harvard University Herbaria. 22 Divinity Avenue, Cambridge, Massachusetts 02138. U.S.A.

${ }^{4}$ Francisco de Montejo, Mérida 97203, Yucatán, México

${ }^{5}$ Author for correspondence: rolito22@hotmail.com

\begin{abstract}
Cohniella amazonica (Orchidaceae, Oncidiinae, Trichocentrum-clade) a species in the Cohniella ascendens complex, from Amazonas, Venezuela, is herein newly described, illustrated, and characterized based on morphological characters. The new taxon is similar to $C$. nuda, from which it differs in the subquadrateoblong lateral lobes of the labellum that are in the same plane as the central lobe, the 5-partite callus, the bipartite column wings, and the distribution range restricted to the northeastern portion of Amazonas, Venezuela. The conservation status of the new taxon is assessed as Data Deficient (DD) according to the IUCN (International Union for Conservation of Nature) criteria. We provide a key and table of characters to diagnose the Cohniella ascendens species complex, a comparative figure, and a map showing the geographical distributions of the species in this group.
\end{abstract}

Resumen: Cohniella amazonica (Orchidaceae, Oncidiinae, clado-Trichocentrum), una especie en el complejo Cohniella ascendens de Amazonas, Venezuela, es aquí descrito, ilustrado y caracterizado con base en caracteres morfológicos. El nuevo taxón es similar a C. nuda, de la cual se distingue por los lóbulos laterales del labelo subcuadrado-oblongos que se encuentran en el mismo plano que el lóbulo central, el callo 5-partito, las alas de columna bipartitas y la distribución restringida a la porción noreste de Amazonas, Venezuela. El estado de conservación del nuevo taxón es evaluado como Datos Deficientes (DD) de acuerdo a los criterios de la UICN (Unión Internacional para la Conservación de la Naturaleza). Proporcionamos una clave y una tabla de caracteres para diagnosticar las especies del complejo Cohniella ascendens, una figura comparativa y un mapa que muestra sus distribuciones geográficas de las especies de este grupo.

Key words: Cohniella, Trichocentrum, Oncidiinae, Orchidaceae, Venezuela

The genus Cohniella Pfitzer includes 22 species, two natural hybrids, and five informal species complexes (Cetzal-Ix et al. 2013a). The genus is distinguished from others members of the Oncidiinae by the relatively small $(<13 \mathrm{~mm})$ and subspherical, 1-leaved pseudobulbs whose sheaths lack foliar blades, succulent, medium sized to large terete leaves, and Oncidium-like flowers (Carnevali et al. 2010); furthermore, anatomical characters such as unifacial leaves and the presence raphides in the epidermis (Cetzal-Ix et al. 2013b) also help distinguish the genus. Characters used to recognize species are primarily

* This contribution was prepared as part of the special edition of LANKESTERIANA that is dedicated to the commemoration of Lankester Botanical Garden's (JBL) 40th anniversary. Botanical collections of the JBL have been relevant to understand the identity and distribution of Cohniella species in our previous studies, cited in this paper. 
floral, such as the shape and position of the lateral lobes of the labellum, shape, position, and number of teeth of the callus of the labellum, shape and size of the column base, and shape and position of the column wings (Cetzal-Ix et al. 2013a). Regarding the species complexes, they are recognized by combinations of vegetative and floral characters. The vegetative characters include the size and thickness of the leaves, the length of the inflorescence relative to subtending leaf, the position, number, and the arrangement of flowers in the inflorescence. Floral characters useful in species diagnoses include size and color of the flowers, the shape of the platform of the labellum callus, and the shape and presence or absence of the base of the column.

Furthermore, species or species complexes can be easily identified using these characters in combination with discrete patterns of ecological and geographical distribution. The five species complexes in Cohniella are morphologically, ecologically, and geographically discrete; moreover, they are recovered as monophyletic in morphological and molecular phylogenetic analyses (Cetzal-Ix 2012a).

The Cohniella ascendens complex includes $C$. aguirrei (Königer) Königer, C. ascendens (Lindl.) Christenson, C. helicantha (Kraenzl.) Cetzal \& Carnevali, C. lacera (Lindl.) Cetzal, and C. nuda (Bateman ex Lindl.) Christenson (Table 1). Its species occur in humid to subhumid habitats, from low-statured inundated, semi-evergreen to evergreen forests and, more rarely, in semideciduous forest at elevations of 0-800 meters. Members of the Cohniella ascendens complex share a habit featuring the semipendulous or semi-erect leaves with rarely racemose or paniculate inflorescences that usually do not exceed the length of the leaf, more infrequently exceeding it; furthermore, the sepals are rounded whereas the petals are subquadrate with subtruncate apex; the callus of the labellum presents a hemispherical platform. Species are distributed from northern Tamaulipas and the central portion of Mexico to the northern and northwestern Colombia and the northern half of Venezuela. Cohniella ascendens and C. nuda present the widest distributions within the complex (and the genus); other species, such as C. aguirrei and C. lacera, are much more geographically restricted (Figure 1). n 1995 a plant collected by Carlos García Esquivel in an area of tropical humid forests with a strong dry season in northwestern Amazonas state, Venezuela was identified as Oncidium cebolleta (Jacq.) Sw. by one of us (GC). However, despite this plant has morphological features characteristic of the Cohniella ascendens complex. We here interpret the combination of morphological characters and distribution as evidence of species status for this plant, which is herein proposed as the new species

Material and methods. The description of the new species was prepared from herbarium material preserved in a 70:25:5 ethanol:water:glycerine solution. Additional material of related species used for this study has been previously cited in Cetzal-Ix \& Carnevali (2010) and Cetzal-Ix (2012b) where flowers from herbarium material were soaked in concentrated ammonium hydroxide for about one minute for rehydration, then rinsed in water until soft and ready for study under a dissecting microscope. Flowers thus pretreated were temporarily preserved as above for further study and eventually returned to herbarium sheets. Pictures of live and herbarium flowers were taken with a SONY Cybershot DSC-W120; others were digitalized under an Epson Expression 1640 XL scanner. Digital images of flowers were captured at several resolutions, ranging from 600 to $1200 \mathrm{dpi}$. Digital line drawings were produced with Canvas X, using the digital images previously captured to provide outlines. Cartography was produced by plotting the locality data cited here and previous studies of CetzalIx \& Carnevali (2010) and Cetzal-Ix (2012b) on an image data "shaded and colored SRTM elevation model” (NASA/JPL/NIMA 2002) using ArcView 3.2 (ESRI 1999).

\section{Taxonomic treatment}

Cohniella amazonica Cetzal \& Carnevali, sp. nov. (Figs. 1-4)

Type: VENEZUELA. Amazonas: Puerto Ayacucho, flowered in cultivation in the collection of Carlos García Esquivel in Caracas, Venezuela; leaf terete; flowers yellow, Dec. 1991, C. García Esquivel s.n. sub. G. Carnevali 3080 (holotype: CICY; isotypes, AMES, VEN). . 


\begin{tabular}{|c|c|c|c|c|c|c|c|c|c|c|c|c|c|c|c|}
\hline 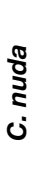 & $\begin{array}{l}\stackrel{8}{0} \\
\stackrel{1}{N}\end{array}$ & $\begin{array}{l}\text { 0) } \\
\frac{1}{1} \\
8\end{array}$ & 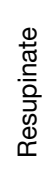 & $\begin{array}{l}0 \\
\stackrel{\dot{\omega}}{\omega}\end{array}$ & $\begin{array}{l}\text { 울 } \\
\dot{b} \\
x \\
x \\
p \\
\dot{m}\end{array}$ & 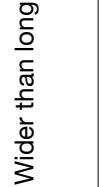 & 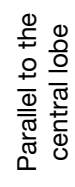 & 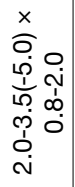 & 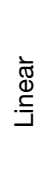 & 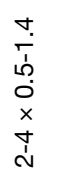 & 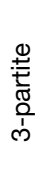 & 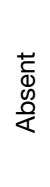 & $\begin{array}{l}\overline{\widetilde{J}} \\
\stackrel{\widetilde{J}}{\overline{0}} \\
0\end{array}$ & $\begin{array}{l}F \\
\overline{0} \\
\text { है } \\
\text { की }\end{array}$ & 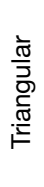 \\
\hline 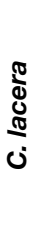 & $\begin{array}{l}\stackrel{P}{1} \\
\stackrel{1}{N}\end{array}$ & 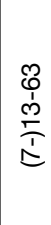 & 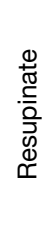 & 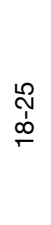 & 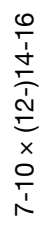 & 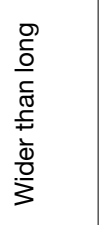 & 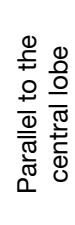 & 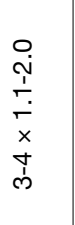 & 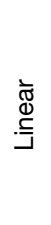 & 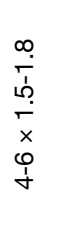 & 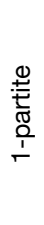 & $\begin{array}{l}\text { त्र } \\
\text { D } \\
\text { 定 }\end{array}$ & $\begin{array}{l}\overrightarrow{\tilde{D}} \\
\text { D } \\
\text { 定 }\end{array}$ & 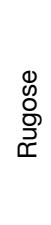 & 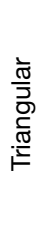 \\
\hline 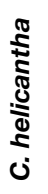 & 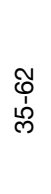 & $\begin{array}{l}\stackrel{\infty}{+} \\
\stackrel{1}{N} \\
\sim\end{array}$ & 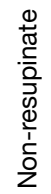 & $\begin{array}{l}\frac{1}{2} \\
\stackrel{1}{\circ}\end{array}$ & 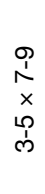 & 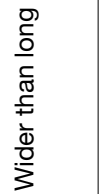 & 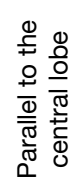 & $\begin{array}{l}0 \\
\grave{i} \\
\hat{1} \\
0 \\
x \\
0 \\
\stackrel{\sim}{N}\end{array}$ & 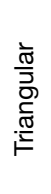 & 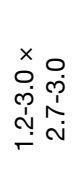 & 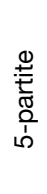 & 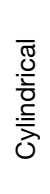 & $\begin{array}{l}\overline{\widetilde{J}} \\
\frac{.}{\bar{\delta}} \\
0\end{array}$ & $\begin{array}{l}0 \\
0 \\
\stackrel{0}{\vec{D}} \\
\stackrel{\vec{D}}{\alpha}\end{array}$ & $\begin{array}{l}\frac{\Phi}{\omega} \\
\stackrel{\omega}{\omega}\end{array}$ \\
\hline 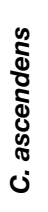 & 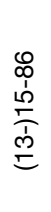 & $\begin{array}{l}0 \\
0 \\
0 \\
10 \\
0 \\
1 \\
1 \\
+1 \\
1 \\
\end{array}$ & 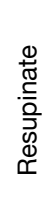 & $\begin{array}{l}\text { N } \\
\stackrel{1}{\circ}\end{array}$ & 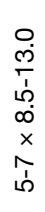 & 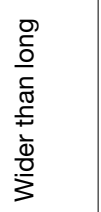 & 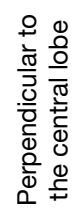 & $\begin{array}{l}\stackrel{+}{\sim} \\
\stackrel{\sim}{\sim} \\
\times \\
\infty \\
\dot{\forall}\end{array}$ & $\begin{array}{l}\text { D } \\
\text { 응 } \\
\text { O }\end{array}$ & 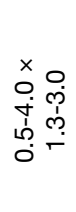 & 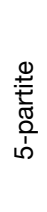 & 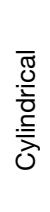 & $\begin{array}{l}\overline{\widetilde{J}} \\
\frac{.}{\bar{\delta}} \\
0\end{array}$ & $\begin{array}{l}0 \\
\mathscr{D} \\
\stackrel{0}{\not} \\
\stackrel{D}{\not}\end{array}$ & 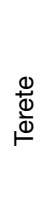 \\
\hline 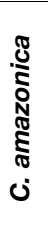 & 1 & $\stackrel{\llcorner}{\sim}$ & 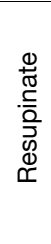 & $\begin{array}{l}\stackrel{\infty}{\Gamma} \\
\stackrel{1}{\circ}\end{array}$ & $\begin{array}{c}0 \\
1 \\
\omega \\
x \\
1 \\
\infty \\
m\end{array}$ & 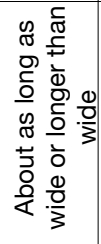 & 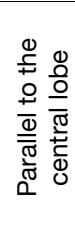 & $\begin{array}{l}0 \\
\dot{+} \\
\dot{L} \\
\infty \\
\dot{x} \\
x \\
\dot{1} \\
\dot{y}\end{array}$ & $\begin{array}{l}\text { D) } \\
\text { 응 } \\
\text { O }\end{array}$ & 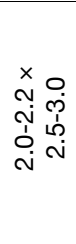 & 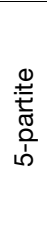 & $\begin{array}{l}\overline{\widetilde{J}} \\
\stackrel{0}{\bar{\nu}} \\
0\end{array}$ & 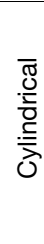 & $\begin{array}{l}\text { Fै } \\
\text { ठ } \\
\text { है }\end{array}$ & $\begin{array}{l}\overline{0} \\
\stackrel{0}{0} \\
\stackrel{0}{\overline{0}}\end{array}$ \\
\hline ڤ్ & $\begin{array}{l}\hat{0} \\
\dot{1} \\
\text { Oे }\end{array}$ & $\begin{array}{l}0 \\
\stackrel{0}{p} \\
+\end{array}$ & 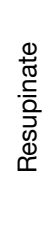 & $\stackrel{\infty}{\bar{b}_{0}}$ & 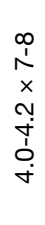 & 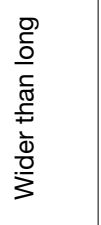 & 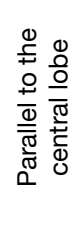 & $\begin{array}{l}p \\
\sim \\
\sim \\
x \\
L \\
\infty \\
m\end{array}$ & 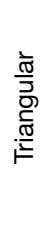 & 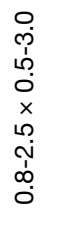 & 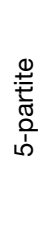 & 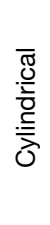 & $\begin{array}{l}\overline{\widetilde{J}} \\
\frac{.}{\bar{\delta}} \\
0\end{array}$ & $\begin{array}{l}0 \\
0 \\
0 \\
\text { D్ } \\
\widetilde{\nabla}\end{array}$ & \\
\hline $\begin{array}{l}\frac{n}{5} \\
\frac{0}{0} \\
\frac{\pi}{\pi} \\
\frac{\pi}{0} \\
\text { U. }\end{array}$ & 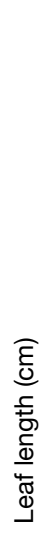 & 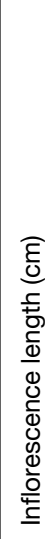 & 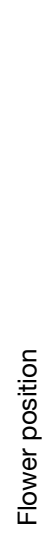 & 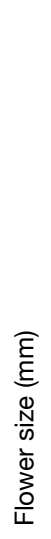 & 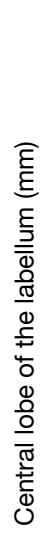 & 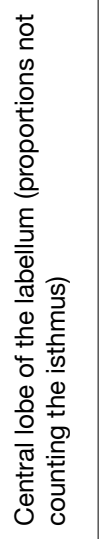 & 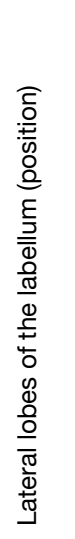 & 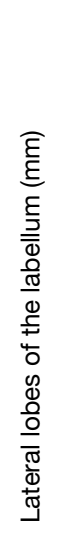 & 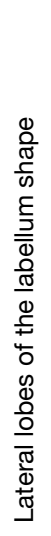 & 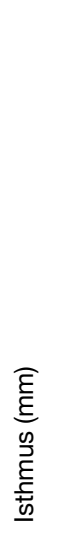 & 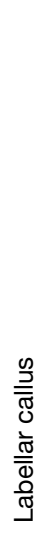 & 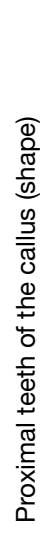 & 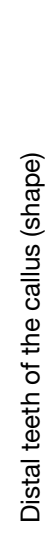 & 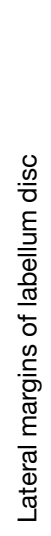 & 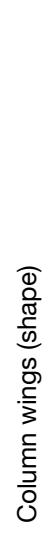 \\
\hline
\end{tabular}




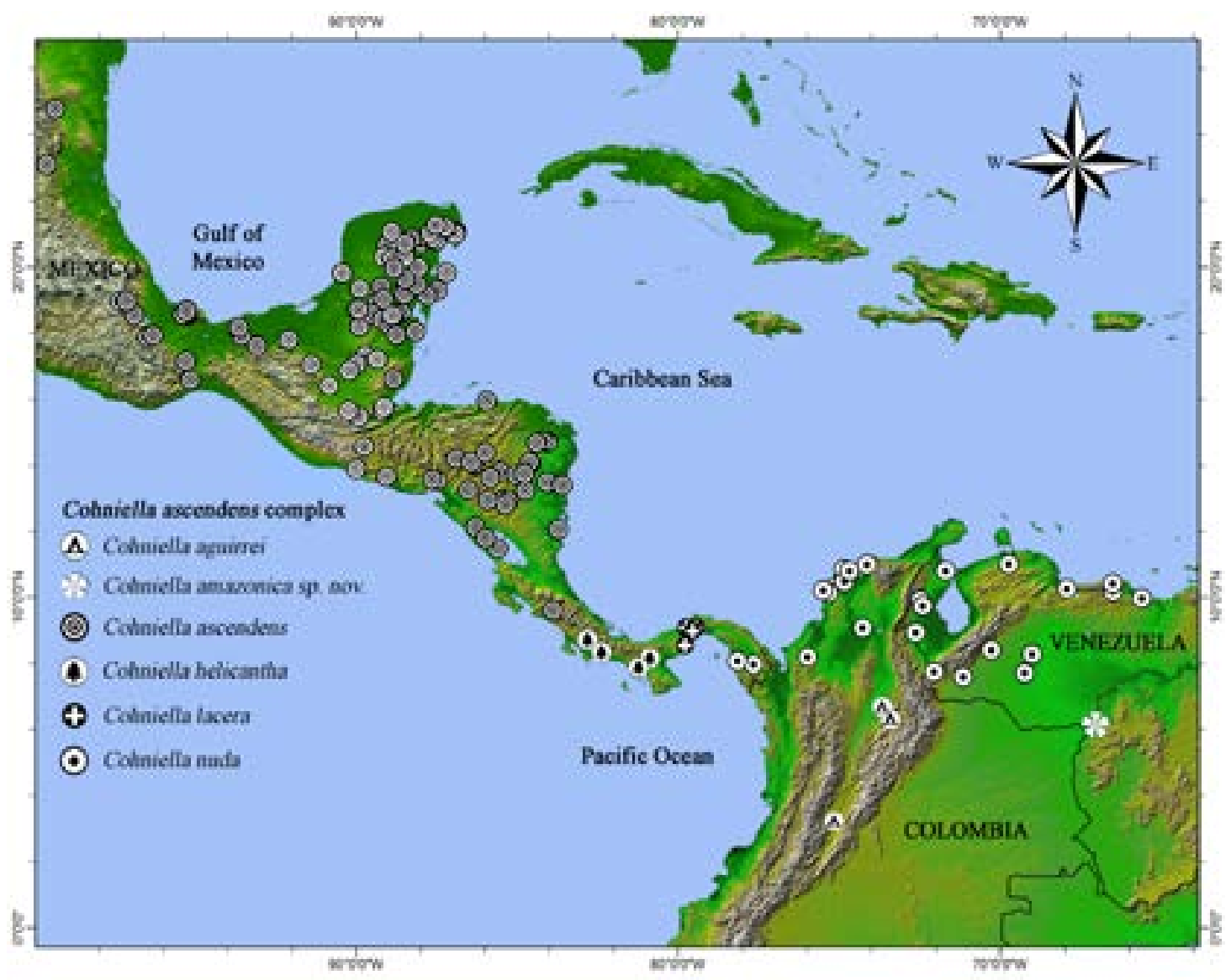

FIGURE 1. Distribution of the Cohniella ascendens species complex.

A Cohniella species belonging to the Cohniella ascendens complex and related to C. nuda from which it is different by the subquadrate-oblong lateral lobes of the labellum that are in the same plane as the central lobe, the 5-partite callus, the bipartite column wings, and distribution restricted to the northeastern portion of Amazonas, Venezuela.

Plant epiphytic. Leaf terete, missing from the only specimen available. Inflorescences presumably solitary and borne from the base of the pseudobulbs, to 25 $\mathrm{cm}$ long, a 9-flowered raceme; peduncle erect, 1.5 $\mathrm{mm}$ thick, terete, with 7 bracted internodes, peduncle bracts $6.0-8.0 \times 2.5-3.0 \mathrm{~mm}$, the basal-most longest, acuminate, tubular; floral bracts $2.0-2.5 \times 0.5-1.0 \mathrm{~mm}$, narrowly elliptic, acuminate. Flowers resupinate, 15-18 $\mathrm{mm}$ diameter, ovary with pedicel $13-17 \mathrm{~mm}$ long, of which 3-4 mm corresponds to the ovary, $0.8-1.0 \mathrm{~mm}$ thick. Sepals basally clawed, spreading or somewhat reflexed. Dorsal sepal 6-7 × 5.5-6.5 mm, obovate, apically obtuse and minutely apiculate, concave in the upper half, the claw $1.0-1.2 \times 1.0-1.1 \mathrm{~mm}$. Lateral sepals partially fused at the very base, then free, similar to dorsal, $6.0-7.0 \times 5.5-6.5 \mathrm{~mm}$. Petals $6-7 \times$ 3-5 mm, oblong to oblanceolate, somewhat oblique, the apex rounded. Labellum 3-lobed, 10-11 mm long from the base to the apex of the central lobe, $8-11 \mathrm{~mm}$ wide across the apices of the lateral lobes, the lateral lobes in the same plane as the central lobe and more or less perpendicular to it. Central lobe 3-5 × 5-6 mm, oblong-spathulate in outline, apically rounded, basally produced into a long isthmus, $2.0-2.2 \times 2.5-3.0 \mathrm{~mm}$. Lateral lobes $4.0-6.0 \times 3.5-4.0 \mathrm{~mm}$, patent, somewhat reflexed in natural position, subquadrate to oblong, apically truncate-rounded, the upper and lower margins of the lateral lobes entire. Disc 3.5-4.0 × 3.5-4.0 mm, 


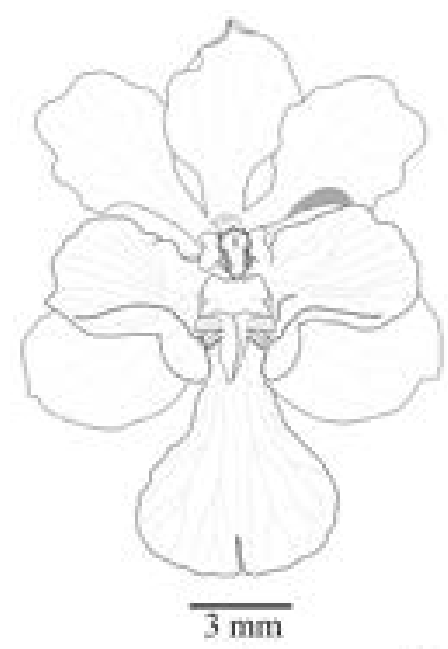

A

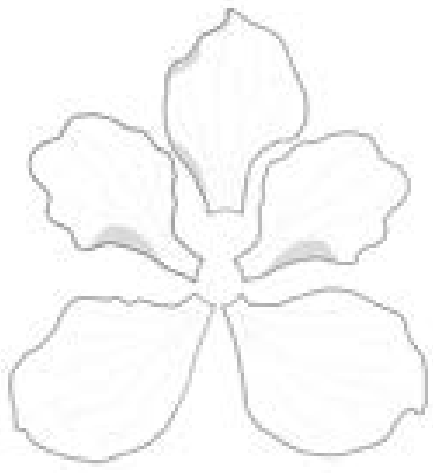

B

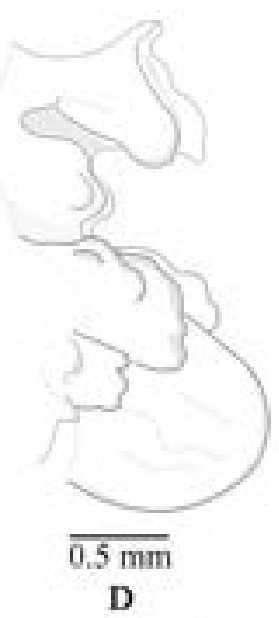

D
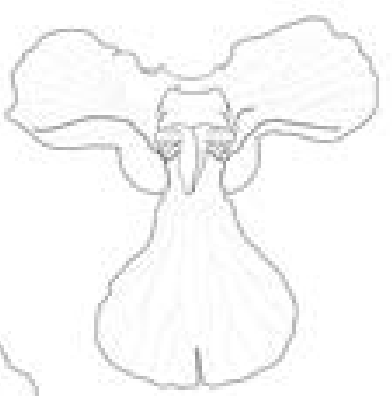

C
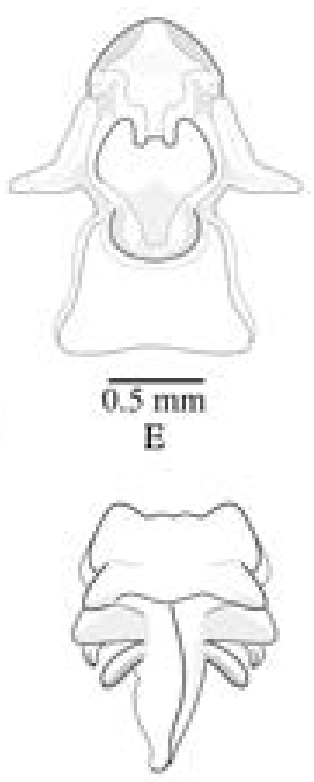

F

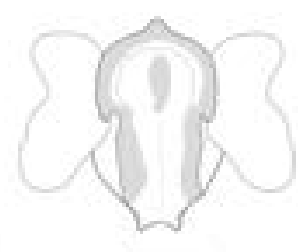

$\overline{1 \mathrm{~mm}}$

G

Figure 2. Cohniella amazonica. A - Flower. B, C - Labellum front view. D - Labellum back view. E - Sepals and petals. F - Disc and callus. G - Flower, lateral view. H C Column, front view. I - clinandrium, front view. Scale: A $=2 \mathrm{~cm}$. B-E. $=6 \mathrm{~mm} . \mathrm{F}=2 \mathrm{~mm} . \mathrm{G}=3 \mathrm{~mm}$. H-I $=1 \mathrm{~mm}$. Drawn by W. Cetzal-Ix.

in general outline oblong, with a well-developed callus, ca. $2.2-2.5 \times 2.5-2.8 \mathrm{~mm}$, consisting of a large, more or less elevated and flat, hemispherical platform $c a$. $1.0-1.2 \times 2.5-2.6 \mathrm{~mm}$, basally with two lateral smaller, divergent, teeth that are conical and point upward, 1.0 $1.2 \mathrm{~mm}$ long, distally with two divergent, cylindrical lateral teeth, these $0.4-05 \times 0.2-0.3 \mathrm{~mm}$; the central tooth $1.8 \mathrm{~mm}$ tall, laterally compressed, the lateral sides of the callus with two small, conical teeth, 0.5 $\mathrm{mm}$ tall. Column $2.5-3.0 \times 1.0-1.2 \mathrm{~mm}$, the ventral face perpendicular to the plane of the labellum lobes, ovate, subcylindric, tabula infrastigmatica subquadrate, stigmatic surface obovate, ca. $0.8 \times 0.6 \mathrm{~mm}$. Column wings $1.0-1.2 \times 0.7-0.8 \mathrm{~mm}$, bilobed, oblate. Anther cap $1.5-1.6 \times 1.2-1.3 \mathrm{~mm}$, apically operculate, obovate. Pollinarium and capsule not seen.

Etymology: The specific epithet refers to the Amazonas state of Venezuela where the only known specimen was collected.

Distribution and ECOlogy. Cohniella amazonica is only known from the vicinity of Puerto Ayacucho in Amazonas State, Venezuela (Fig. 1). It grows in tropical humid forests, possibly in sympatry or parapatry with 

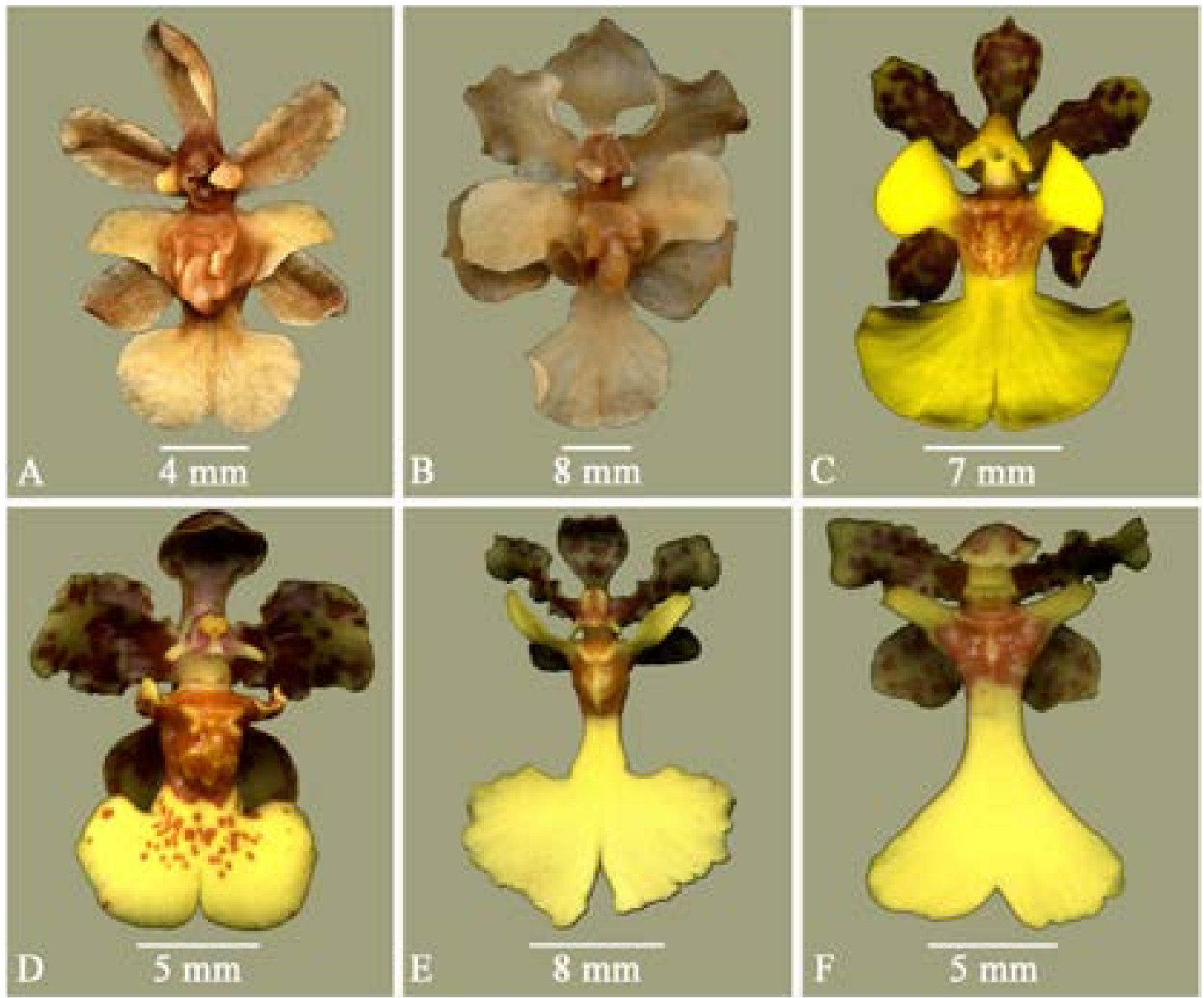

FiguRE 3. Morphological comparison of the Cohniella ascendens species complex. A - Cohniella aguirrei [based on Königer 95, M]. B - Cohniella amazonica [Carnevali 3080, CICY]. C - Cohniella ascendens [Cetzal 17, CICY]. D - Cohniella helicantha [Carnevali 7027, CICY]. E - Cohniella lacera [Carnevali 7311, CICY]. F — Cohniella nuda [Carnevali 7283, CICY].

C. cebolleta (Jacq.) Christenson, C. croizatii Cetzal \& Carnevali, and C. ultrajectina Cetzal \& Carnevali. However, these last three species are part of the Cohniella cebolleta complex which is characterized by the lateral margins of the disc convex with conical teeth, the column base conspicuous, 5-partite callus (3-partite in C. croizatii), the disc covered by brown or reddish spots only at base, and the platform of the callus rectangular (absent in C. croizatii) (Cetzal-Ix et al. 2013a). The hemispherical platform of the callus (Figs. 2F-4B) and relatively narrow central lobe, oblong-spathulate in outline and narrower than long renders this new species unmistakable among other Cohniella species of the area (Fig. 2A-C).
Cohniella amazonica, it is easy to distinguish from related species in the Cohniella ascendens complex such as $C$. aguirrei, $C$. ascendens, and $C$. helicantha by the narrow central lobe to the labellum (Fig. 3). Furthermore, the callus features conical lateral teeth at the base whereas distal calli are cylindrical; this pattern is reversed in the related taxa (Figs. 3-4).

IUCN Red List category. According to IUCN (2004), Cohniella amazonica would be considered as Data Deficient (DD). The species in known a single collection from the Puerto Ayacucho area, it is therefore suspected to be under no special threat, as this area is largely uninhabited except for a few indigenous tribes, primarily Yekuana. However, albeit the region around 


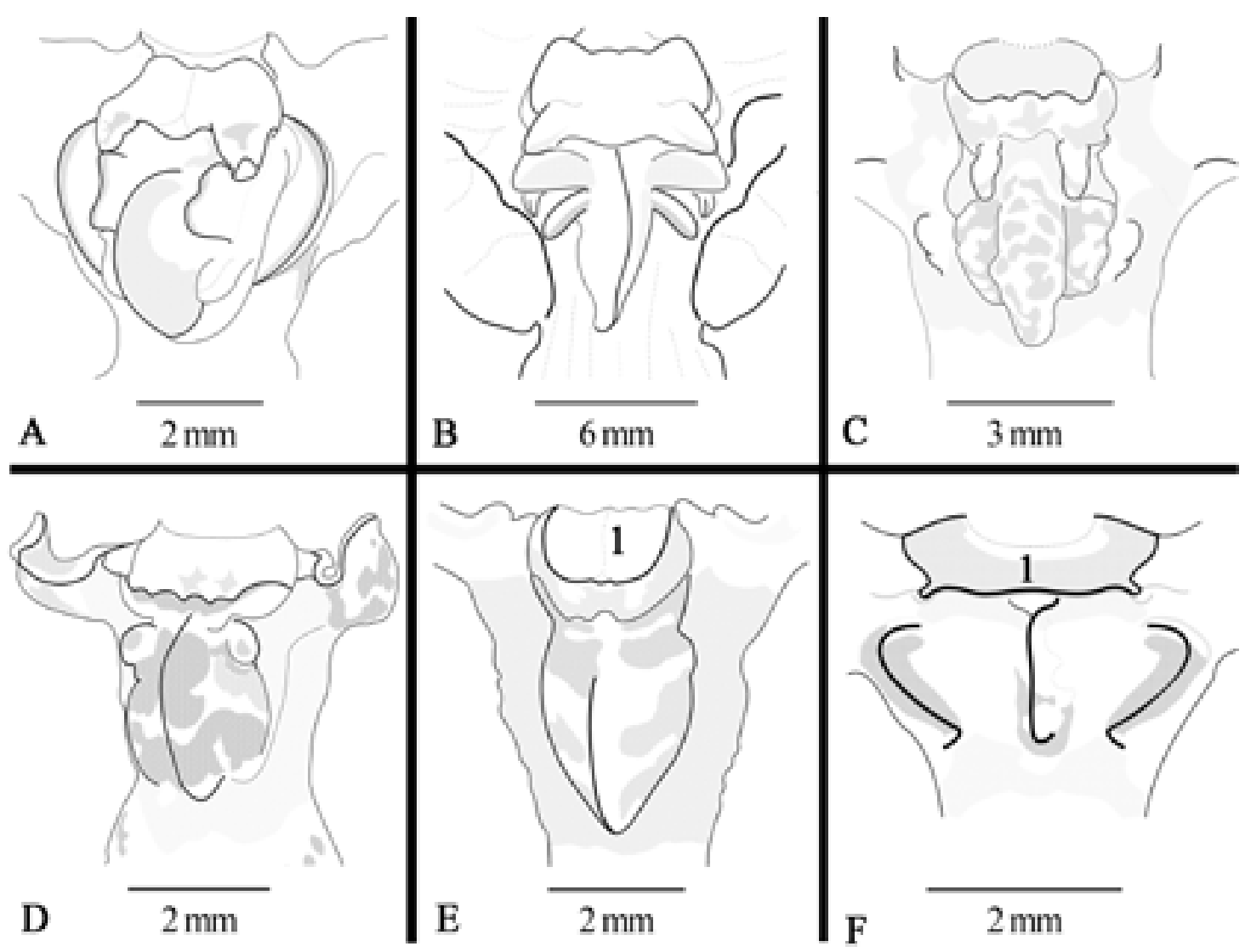

FIgURE 4. Comparison of the labellum callus of the Cohniella ascendens species complex. A - Cohniella aguirrei (based on material type). B - Cohniella amazonica. C - Cohniella ascendens. D - Cohniella helicantha. E - Cohniella lacera. F - Cohniella nuda. Drawn by W. Cetzal-Ix.

Puerto Ayacucho has been severely altered during the past few decades, there are still abundant forested patches in this area (Cetzal-Ix \& Carnevali 2011).

KEY TO THE SPECIES OF THE COHNIELLA ASCENDENS COMPLEX

1. Isthmus of the labellum much longer than broad (2-4 $\times 0.5-2.0 \mathrm{~mm})$; callus consisting of 1 to 3 teeth or keels

\section{2}

1. Isthmus of the labellum approximately as long as broad $(0.5-4.0 \times 0.5-3.0 \mathrm{~mm})$; callus consisting of 5 teeth or keels 3

2. Flowers $18-25 \mathrm{~mm}$ diameter; labellum with the lacerated margin; column wings conspicuous; callus of the labellum 1-partite; plants endemic to the central portion of Panama C. lacera

2. Flowers $13-16 \mathrm{~mm}$ diameter; labellum with the entire or slightly lacerated; column wings reduced or absent; callus of the labellum 3-partite; plants from the eastern portion of Panama and northern Colombia and Venezuela

C. nuda

3. Central lobe of the labellum 5-6 mm wide; lateral margins of the labellum smooth; column wings bipartite; plants from Venezuela C. amazonica

3. Central lobe of the labellum 7-13 mm wide; lateral margins of the labellum rugose; column wings terete; plants from Mexico to Colombia

4

4. Flowers non resupinate; lateral lobes of the labellum triangular, short and thin (2-3 $\times$ 0.7-1.0 mm); plants from Panama and Colombia C. helicantha

4. Flowers resupinate; lateral lobes of the labellum various (obovate, oblong or triangular), lengths and widths $(3-8 \times 2-4$ $\mathrm{mm}$ ); plants from Mexico to Colombia 5 
5. Lateral lobes of the labellum erect, usually spathulate, broadly obovate; column wings terete; plants of northwestern Mexico to the southeast of Costa Rica

C. ascendens

5. Lateral lobes of the labellum patent, not spathulate, oblong-triangular; column wings subtriangular; plants from the valleys between the central and eastern Andean Cordilleras from Colombia

C. aguirrei

AcKnowledgements. We thank Franco Pupulin (JBL) for inviting us to participate in this special issue of Lankesteriana. Gustavo A. Romero-González (AMES) and Rodrigo Duno (CICY) commented on earlier drafts of this article. Silvia Hernández Aguilar (CICY) helped us with the management of herbarium loans.

\section{Literature Cited}

Carnevali, G., W. Cetzal-Ix, R. Balam-Narváez \& G.A. Romero-González. 2010. A synopsis of Cohniella (Orchidaceae, Oncidiinae). Brittonia 62(2): 153-177.

Cetzal-Ix, W. 2012a. Sistemática, Filogenia y Biogeografía de Cohniella Pfitzer (Orchidaceae: Cymbidieae,
Oncidiinae). El Colegio de la Frontera Sur, Chetumal, Quintana Roo, 276 pp.

Cetzal-Ix, W. 2012b. Oncidium lacerum, an older and ignored name for Cohniella stipitata (Orchidaceae, Cymbideae, Oncidiinae). Ann. Bot. Fenn. 49(1-2): 137-143.

Cetzal-Ix, W. \& G. Carnevali. 2010. A revision of Cohniella Pfitzer (Orchidaceae) in Mexico. J. Torrey Bot. Soc. 137(2-3): 180-213.

Cetzal-Ix, W. \& G. Carnevali. 2011. A new Cohniella Pftizer (Orchidaceae, Cymbidieae, Oncidiinae) from Amazonian Venezuela. Novon 21(2): 178-181.

Cetzal-Ix, W., G. Carnevali, E. Noguera-Savelli \& G.A. Romero-González. 2013a. Really, what is Cohniella cebolleta? A recircumscription plus new and resurrected species and combinations. Syst. Bot. 38(3): 1-18.

Cetzal-Ix, W., E. Noguera-Savelli, D. Jauregui \& G. Carnevali. 2013b. Anatomía foliar comparada y sistemática del clado-Trichocentrum con énfasis en Cohniella (Asparagales: Orchidaceae). Rev. Biol. Trop. 61(4): 1-20.

ESRI. 1999. ArcView gis 3.2, Environmental Systems Research Institute, Inc. New York.

IUCN. 2004. Guidelines for using the IUCN red list categories and criteria. Rapport IUCN. Gland, Switzerland and Cambridge, UK, $50 \mathrm{pp}$.

NASA/JPL/NIMA. 2002. NASA, Jet Propulsion Laboratory. NASA Earth Science Enterprise, Washington, D.C. Available from http://photojournal.jpl.nasa.gov/catalog/ PIA03364 (accessed: 20 July 2013). 